\title{
Tetrazine Chromophore-Based Metal-Organic Frameworks with Unusual Configurations: Synthetic, Structural, Theoretical, Fluorescent and Nonlinear Optical Studies
}

\author{
Jianghua Li, ${ }^{\left[{ }^{[a]}\right.}$ Ding Jia, ${ }^{\text {[a] }}$ Suci Meng, ${ }^{[a]}$ Jinfang Zhang, ${ }^{[a]}$ Marie P. Cifuentes, ${ }^{[b]}$ Mark G. \\ Humphrey, ${ }^{[b]}$ and Chi Zhang*[a,b] \\ [a] China-Australia Joint Research Center for Functional Molecular Materials, Scientific Research \\ Academy, Jiangsu University, Zhenjiang 212013, P. R. China \\ ${ }^{[b]}$ Research School of Chemistry, Australian National University, Canberra, ACT 2601, Australia
}

Abstract: Three unusual three-dimensional (3D) tetrazine chromophore-based metal-organic frameworks (MOFs) $\left\{\left(\mathrm{Et}_{4} \mathrm{~N}\right)\left[\mathrm{WS}_{4} \mathrm{Cu}_{3}(\mathrm{CN})_{2}\left(4,4^{\prime}-\mathrm{pytz}\right)_{0.5}\right]\right\}_{n} \quad$ (1), $\left\{\left[\mathrm{MoS}_{4} \mathrm{Cu}_{4}(\mathrm{CN})_{2}\left(4,4^{\prime}-\mathrm{pytz}_{2}\right] \cdot \mathrm{CH}_{2} \mathrm{Cl}_{2}\right\}_{n}\right.$ (2), and $\left\{\left[\mathrm{WS}_{4} \mathrm{Cu}_{3}\left(4,4^{\prime}-\mathrm{pytz}\right)_{3}\right] \cdot\left[\mathrm{N}(\mathrm{CN})_{2}\right]\right\}_{n}$ (3) (4,4'-pytz = 3,6-bis(4-pyridyl)tetrazine) have been synthesized and characterized by Fourier-transform infrared and ultraviolet/visible spectroscopies, elemental analyses, powder X-ray diffraction, gel permeation chromatography, steady-state fluorescence, and thermogravimetric analyses, and their identities have been unambiguously confirmed by single-crystal X-ray diffraction studies. These MOFs exhibit diverse configurations. 1 possesses the first 5-connected M/S/Cu (M = Mo, W) framework, with an unusual 3D $\left(4^{4} \cdot 6^{6}\right)$ topology constructed from T-shaped $\left[\mathrm{WS}_{4} \mathrm{Cu}_{3}\right]^{+}$clusters as nodes and single $\mathrm{CN}^{-} / 4,4^{\prime}$-pytz bridges as linkers. 2 features a novel 3D MOF with $\left(4^{20} \cdot 6^{8}\right)$ topology, in which the bridging 4,4'-pytz ligands exhibit unique distorted arch structures. 3 displays the first 3D MOF based on flywheel-shaped $\left[\mathrm{WS}_{4} \mathrm{Cu}_{3}\right]^{+}$clusters, with a non-interpenetrating honeycomb-like framework and a heavily distorted "ACS" topology. Steady-state fluorescence studies of 1-3 reveal significant fluorescence emissions. The nonlinear optical (NLO) properties of 1-3 were investigated by the Z-scan technique employing $5 \mathrm{~ns}$ pulses at $532 \mathrm{~nm}$. The Z-scan experimental results show that the $\pi$-delocalizable 
tetrazine-based 4,4'-pytz ligands contribute to the strong third-order NLO properties exhibited by 1-3. Time-dependent density functional theory (TD-DFT) studies have afforded insight into the electronic transitions and spectral characterization of these functionalized NLO molecular materials.

Keywords: metal-organic frameworks · tetrazine chromophore · structural elucidation $\cdot$ density functional calculations $\cdot$ nonlinear optics

Corresponding Author:

Professor Dr. Chi Zhang: Fax: +86-511-88797815, E-mail: chizhang@ujs.edu.cn

Supporting information for this article is available on the WWW under http://dx.doi.org/10.1002/chem.2014xxxxx. It includes the powder X-ray diffraction patterns of 1-3 (Figure S1), thermogravimetric analyses of 1-3 (Figure S2), the configurations of the bpp and 4,4'-pytz ligands (Figure S3), the tetrahedral coordination modes of the nest-shaped cluster and the flywheel-shaped cluster (Figure S4), and B3LYP/LanL2DZ TD-DFT/PCM calculations (300 states) of 1-3 in DMF solution. 


\section{Introduction}

Cluster-based metal-organic frameworks (MOFs), assembled with metal clusters as nodes and organic ligands as linkers, are attracting intense interest due to their fascinating topological features ${ }^{[1]}$ and their potential applications, ${ }^{[2]}$ particularly as nonlinear optical (NLO) materials. ${ }^{[3]}$ The ongoing research and development in this promising field shows that, in contrast to other NLO-active MOFs, ${ }^{[4]}$ the utilization of metal clusters at the framework vertices is a powerful means of directing the final framework structure and topology, with a significant enhancement/modulation of the NLO properties of the resulting MOFs. ${ }^{[3,5]}$ These MOFs possess the combined advantages of both organic molecules and metal clusters: $\pi$-delocalizable structures and many heavy-metal atoms. One of the most important and promising features of metal clusters is the possibility of adjusting and eventually optimizing these framework building blocks through subtle modifications at the molecular level. The incorporation of heavy-metal atoms (via the use of clusters) may also introduce more sublevels into the energy hierarchy of framework materials, compared to that achievable using organic molecules with the same number of skeletal atoms, permitting more allowed electronic transitions, and thereby leading to larger NLO effects and a greater prospect of NLO applications. ${ }^{[6]}$

While discrete $\mathrm{M} / \mathrm{S} / \mathrm{Cu}(\mathrm{M}=\mathrm{W}$, Mo) clusters have been well-documented to be amongst the best candidates for third-order NLO materials, due to the variety of possible cluster skeletons with their corresponding diverse electronic character, ${ }^{[7]}$ $\mathrm{M} / \mathrm{S} / \mathrm{Cu} \mathrm{MOFs}^{[8]}$ have emerged recently as a new research frontier for advanced third-order NLO materials and devices, ${ }^{[9]}$ due to the fact that such cluster-based organic frameworks can possess extensive $\mathrm{d} \pi$-p $\pi$ delocalized systems and $\mathrm{p} \pi$-p $\pi$ conjugated systems, and may introduce two different d-orbital levels into the molecule. These M/S/Cu MOFs not only contain NLO-functionalized building clusters, but also include conjugated organic ligands, which may permit more electronic transitions and greater $\pi$-electron delocalization, and accordingly enhance/modulate the third-order NLO properties. ${ }^{[5,7]}$ However, the crystal engineering of multidimensional $\mathrm{M} / \mathrm{S} / \mathrm{Cu}$ 
cluster-based organic frameworks with well-defined geometries still faces great challenges to control the complexity and diversity of the frameworks. ${ }^{[7-9]}$ Previous studies have demonstrated that unique framework connectivity, bent or twisted organic bridges, novel cluster units, the necessary counterions or templates, and strongly coordinating terminal ligands increase structural complexity and afford novel MOFs with non-default topologies. ${ }^{[10]}$ Organometallic or organic chromophores (of which tetrazine-based derivatives are important examples ${ }^{[11-13]}$ ) with extensive $\pi$-conjugation can possess enhanced NLO performance. ${ }^{[11]}$ Nevertheless, the coordination of the conjugated chromophore 4,4'-pytz $\left(4,4^{\prime}-\text { pytz }=3,6 \text {-bis(4-pyridyl)tetrazine }\right)^{[13]}$ to metal clusters as a means to synthesize novel 3D tetrazine chromophore-based $\mathrm{M} / \mathrm{S} / \mathrm{Cu}$ MOFs and optimize the third-order NLO properties remains to be explored.

Herein, we report the syntheses, structures, theoretical studies, fluorescence and NLO properties of three unusual 3D tetrazine chromophore-based MOFs. 1-3 have been synthesized from $\left[\mathrm{E}_{4} \mathrm{~N}\right]_{2}\left[\mathrm{MS}_{4}\right](\mathrm{E}=\mathrm{Et}, \mathrm{H} ; \mathrm{M}=\mathrm{Mo}, \mathrm{W})$ and $\mathrm{CuCN} / \mathrm{Cu}\left[\mathrm{N}(\mathrm{CN})_{2}\right]$ with 4,4'-pytz ligands: 1 possesses the first 5-connected M/S/Cu MOF, with an unusual $\left(4^{4} \cdot 6^{6}\right)$ topology that is constructed from T-shaped $\left[\mathrm{WS}_{4} \mathrm{Cu}_{3}\right]^{+}$building clusters with single $\mathrm{CN}^{-}$bridges and single $4,4^{\prime}$-pytz bridges; 2 has a novel 8 -connected $\left(4^{20} \cdot 6^{8}\right)$ topological framework in which pentanuclear planar “open”-shaped $\left[\mathrm{MoS}_{4} \mathrm{Cu}_{4}\right]^{2+}$ cores are connected by unique “distorted arch" 4,4'-pytz bridges and single $\mathrm{CN}^{-}$bridges; and 3 is the first $3 \mathrm{D}$ MOF based on flywheel-shaped $\left[\mathrm{WS}_{4} \mathrm{Cu}_{3}\right]^{+}$clusters, linked by single 4,4'-pytz bridges only, and showing a heavily distorted “ACS” topology. Steady-state fluorescence and third-order NLO measurements of 1-3 indicate that these chromophore cluster-based frameworks possess enhanced NLO performance. Density functional theory (DFT) and time-dependent density functional theory (TD-DFT) calculations provide further insight into the electronic transitions and spectral characterization of these functionalized molecular materials.

\section{Results and Discussion}

\section{Synthetic procedure}

$\mathrm{M} / \mathrm{S} / \mathrm{Cu}(\mathrm{M}=\mathrm{Mo}, \mathrm{W})$ cluster-based MOFs can be far superior to traditional 
MOFs, ${ }^{[4]}$ both in terms of possible configurations ${ }^{[7,8]}$ and in their intriguing NLO properties. ${ }^{[5,9]}$ However, chromophore-based M/S/Cu MOFs with unique 3D structures and modulated NLO properties are still very scarce. In the present studies, 4,4'-pytz ligands have been utilized to construct 3D chromophore-based MOFs, affording disparate molecular configurations for 1-3 by modulating the cations, anions, and stoichiometric ratios; their structural characteristics are described in detail in the following paragraphs.

Single-crystal X-ray structural studies of 1, 2 and $\mathbf{3}$ demonstrate conclusively that their unusual configurations are composed of T-shaped, pentanuclear planar “open”-shaped, and flywheel-shaped clusters, respectively, with 4,4'-pytz/CN bridges; these structures contain 5-connected modes, “distorted arch” bridges, and unusual building clusters, respectively. In principal, the configurations of cluster-based MOFs can be characterized by the connectivity modes, the types of skeleton of the building clusters, and the topological structures. For example, cluster-based MOFs with 4-/8-connected modes, T-shaped/pentanuclear planar “open” building clusters, and diamondoid topology have been the subject of several reports in the literature, ${ }^{[3,7-9]}$ and therefore can be considered to possess well-documented configurations. In contrast, the 3D cluster-based MOFs in the present work with 5-connected modes, flywheel-shaped building clusters, $\left(4^{20} \cdot 6^{8}\right)$, and heavily distorted “ACS” topological structures have not been reported previously and accordingly can be regarded as possessing unusual (indeed, unprecedented) configurations.

Using the so-called inter-diffusion method, ${ }^{[9 \mathrm{~d}]}$ the reaction of $\left[\mathrm{Et}_{4} \mathrm{~N}_{2}\left[\mathrm{WS}_{4}\right]\right.$ and CuCN (mole ratio 1:3) with 4,4'-pytz afforded $\mathbf{1}$ as a T-shaped $\left[\mathrm{WS}_{4} \mathrm{Cu}_{3}\right]^{+}$-containing MOF, the combination of $\left[\mathrm{NH}_{4}\right]_{2}\left[\mathrm{MoS}_{4}\right]$ and $\mathrm{CuCN}$ (mole ratio 1:4) with 4,4'-pytz gave 2 as a pentanuclear planar “open”-shaped $\left[\mathrm{MoS}_{4} \mathrm{Cu}_{4}\right]^{2+}$-containing $\mathrm{MOF}$, and the assembly of $\left[\mathrm{NH}_{4}\right]_{2}\left[\mathrm{WS}_{4}\right]$ and $\mathrm{Cu}\left[\mathrm{N}(\mathrm{CN})_{2}\right]$ (mole ratio 1:3) with 4,4'-pytz afforded 3 as an unexpected 3D flywheel-shaped $\left[\mathrm{WS}_{4} \mathrm{Cu}_{3}\right]^{+}$-containing MOF (Scheme 1). The phase purities of the bulk products of 1-3 were independently confirmed by powder $\mathrm{X}$-ray diffraction (Figure S1 in the Supporting Information).

The inter-diffusion method ${ }^{[9 \mathrm{~d}]}$ employed in these studies utilized a solvent 
polarity-tunable buffer layer to separate the polar and nonpolar solutions, one of which included the soluble $\mathrm{M} / \mathrm{S} / \mathrm{Cu}$ clusters, while the other contained precipitating agents, such as a counterion, a conjugated bridging ligand, etc. When these two solutions diffused into the buffer layer, the M/S/Cu MOFs were formed and crystallized in the buffer layer. Using this method, we also attempted the reactions of $\left[\mathrm{NH}_{4}\right]_{2}\left[\mathrm{MS}_{4}\right]$ and CuCN (mole ratio 1:1 3) /CuN(CN)2 (mole ratio 1:1 2) with 4,4'-pytz. However, no desired M/S/Cu MOFs resulted from the above recipes. Perhaps not surprisingly, these results indicate that the inter-diffusion method, explored as a practical route to construct new MOFs, is strongly influenced by varying the cations, anions and mole ratio of the reactants.

\section{Crystal structure of 1}

Single-crystal X-ray diffraction analysis reveals that $\mathbf{1}$ is the first 5 -connected $\mathrm{M} / \mathrm{S} / \mathrm{Cu} \mathrm{MOF}$ (Figures 1a and $1 \mathrm{~b}$ ). As shown in Figure 1b, the building cluster $\left[\mathrm{WS}_{4} \mathrm{Cu}_{3}\right]^{+}$with a 5-connected mode exhibits $C_{1}$ symmetry, in which the $\mathrm{Cu}(3)-\mathrm{W}(1)-\mathrm{Cu}(1), \mathrm{Cu}(2)-\mathrm{W}(1)-\mathrm{Cu}(1)$, and $\mathrm{Cu}(3)-\mathrm{W}(1)-\mathrm{Cu}(2)$ angles are 91.04(3) ${ }^{\circ}$, $90.79(3)^{\circ}$, and $177.24(2)^{\circ}$, respectively, giving rise to a nearly T-shaped arrangement for each $\left[\mathrm{WS}_{4} \mathrm{Cu}_{3}\right]^{+}$building cluster. The $\mathrm{W}$ atom possesses a tetrahedral coordination geometry through bonding to two $\mu_{2}-\mathrm{S}$ and two $\mu_{3}-\mathrm{S}$ atoms, with the S-W-S angles ranging from $107.67(6)^{\circ}$ to $111.26(6)^{\circ}$. In each T-shaped building cluster $\left[\mathrm{WS}_{4} \mathrm{Cu}_{3}\right]^{+}$, three $\mathrm{Cu}$ atoms show different coordination environments: $\mathrm{Cu} 1$ is ligated by two $\mu_{3}-\mathrm{S}$ atoms, one $\mathrm{C}$ atom from a $\mathrm{CN}^{-}$bridge, and one $\mathrm{N}$ atom of a 4,4'-pytz ligand, forming a tetrahedral coordination geometry; $\mathrm{Cu} 2$ also has a tetrahedral coordination geometry, but formed by one $\mu_{2}-\mathrm{S}$ atom, one $\mu_{3}-\mathrm{S}$ atom and two $\mathrm{CN}^{-}$bridges; and $\mathrm{Cu} 3$ has a trigonal coordination geometry, formed by one $\mathrm{CN}^{-}$bridge, one $\mu_{2}-\mathrm{S}$ atom, and one $\mu_{3}-\mathrm{S}$ atom (Figure $\left.1 \mathrm{~b}\right)$. The bond lengths of $\mathrm{Cu}-\mu_{2}-\mathrm{S}$ (Cu2-S3, 2.301(19) $\AA$; Cu3-S4, 2.226(18) $\AA$ ) are slightly shorter than those of Cu- $\mu_{3}-\mathrm{S}$ (Cu1-S1, 2.304(16) $\AA$; Cu1-S2,

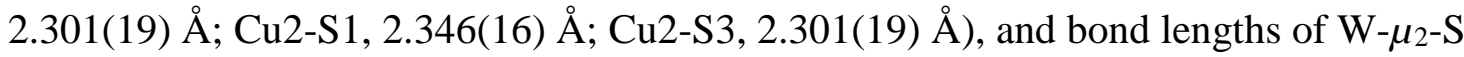

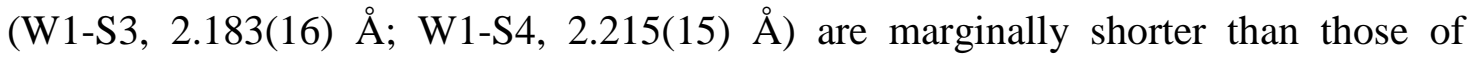
W- $\mu_{3}-\mathrm{S}$ (W1-S1, 2.224(16) $\AA$; W1-S2, 2.259(15) Å), with a concomitant shortening of 
the $\mathrm{W} 1 \cdots \mathrm{Cu} 3$ distances $(2.640(8) \AA$ ) in comparison with the $\mathrm{W} 1 \cdots \mathrm{Cu} 1$ distance (2.727(9) $\AA$ ). The average length of the Cu-C bonds (1.903(1) $\AA$ ) in $\mathbf{1}$ is shorter than that of the Cu-N bonds (2.115(8) $\AA$ ) (Table 2).

Each T-shaped $\left[\mathrm{WS}_{4} \mathrm{Cu}_{3}\right]^{+}$cluster is linked by another five $\left[\mathrm{WS}_{4} \mathrm{Cu}_{3}\right]^{+}$units through one single $4,4^{\prime}$-pytz bridge and four single $\mathrm{CN}^{-}$bridges (Figure $1 \mathrm{~b}$ ); $\mathbf{1}$ is thereby the first 5-connected M/S/Cu MOF. ${ }^{[8,9]}$ The T-shaped $\left[\mathrm{WS}_{4} \mathrm{Cu}_{3}\right]^{+}$building clusters are connected to each other by four single $\mathrm{CN}^{-}$bridges along the $b c$ plane, creating parallel two-dimensional $(2 \mathrm{D})(4,4)$ nets as layer, and then these nets are stacked along the $a$-axis to afford a 3D pillared-layer skeleton sustained by single 4,4'-pytz bridges as pillar (Figure 2). From the topological perspective, each [ $\left.\mathrm{WS}_{4} \mathrm{Cu}_{3}\right]^{+}$building cluster in $\mathbf{1}$ can be regarded as a 5 -connected node and all $\mathrm{CN}^{-}$and 4,4'-pytz ligands as linkers, so 1 can be considered to possess a 5 -connected $\left(4^{4} \cdot 6^{6}\right)$ topology (Figure 3); to the best of our knowledge, this is the first such example of a $\mathrm{Mo}(\mathrm{W}) / \mathrm{S} / \mathrm{Cu}$ polymeric cluster with a 5 -connected network, ${ }^{[8,9]}$ while metal-organic frameworks possessing 5-connected topology are rare. ${ }^{[14]}$

\section{Crystal structure of 2}

The crystal structure analysis of 2 reveals an unusual 3D MOF with "distorted arch” 4,4'-pytz bridges (Figures 4a and 4b; selected bond lengths and bond angles of 2 are given in Table 3). The skeleton of the building cluster is composed of one Mo, four $\mathrm{Cu}$ and four $\mathrm{S}$ atoms, forming a $\left[\mathrm{MoS}_{4} \mathrm{Cu}_{4}\right]$ aggregate in which the Mo atom is in the center of the cluster while both the $\mathrm{Mo}$ and $\mathrm{Cu}$ atoms are approximately tetrahedrally coordinated, resulting in pentanuclear planar "open”-shaped building clusters $\left[\mathrm{MoS}_{4} \mathrm{Cu}_{4}\right]^{2+}$ of pseudo $D_{4 \mathrm{~h}}$ symmetry and five metal atoms that are slightly distorted from planarity; this is consistent with angles Cu1-Mo1-Cu1b and Cu1a-Mo1-Cu1c both being $164.09(2)^{\circ}$ (Table 3). The average Cu-N length of 2 (2.041(9) $\AA$ ) is shorter than that for 1 (2.115(8) $\AA)$.

In each building cluster $\left[\mathrm{MoS}_{4} \mathrm{Cu}_{4}\right]^{2+}$, the four $\mathrm{Cu}$ atoms have the same tetrahedral coordination environments, ligated by two $\mu_{3}-\mathrm{S}$ atoms, one $\mathrm{N}$ atom from one $\mathrm{CN}^{-}$, and one $\mathrm{N}$ atom from one 4,4'-pytz bridge, respectively (Figure 4b). Each $\left[\mathrm{MoS}_{4} \mathrm{Cu}_{4}\right]^{2+}$ 
cluster links another eight equivalent clusters through four single $\mathrm{CN}^{-}$bridges and four single 4,4'-pytz bridges in an 8-connected manner (Figure 4b). A remarkable feature of 2 is that there are "distorted arch" 4,4'-pytz bridges (Figure 4b); to the best of our knowledge, this is the first MOF constructed by such distorted 4,4'-pytz bridges. ${ }^{[15]}$ The degree of bending $\delta$ of the “distorted arch” ligands 4,4'-pytz is 5.13\% (arc height = $0.59 \AA$ and chord length $=11.05 \AA$ ) (Figure 4c), for $\delta$ defined as the ratio of arc height over chord length. ${ }^{[14]}$ Overall, 2 can be viewed as pentanuclear planar “open”-shaped clusters $\left[\mathrm{MoS}_{4} \mathrm{Cu}_{4}\right]^{2+}$ linked to each other by $\mathrm{CN}^{-}$bridges in the $a b$ plane and thereby forming $2 \mathrm{D}(4,4)$ nets as layer, and then these 2D nets stacking along the $c$-axis to afford a 3D pillared-layer MOF linked by “distorted arch” ligands 4,4'-pytz as pillar (Figure 5). Each pentanuclear planar “open”-shaped cluster occupies a topological 8-connected node, and all $\mathrm{CN}^{-}$and 4,4'-pytz ligands serve as linkers; 2 accordingly possesses an 8-connected framework with a $\left(4^{20} \cdot 6^{8}\right)$ topology (Figure 6). This is only

the second 8-connected $\mathrm{Mo} / \mathrm{S} / \mathrm{Cu} \mathrm{MOF}$ thus far, ${ }^{[16]}$ but the precedent framework has $\left(4^{22} \cdot 6^{6}\right)$ topology, possibly a result of different configurations from the flexible ligand bpp (bpp = bis(4-pyridyl)propane) than from the “distorted arch” ligand 4,4'-pytz (Figure S3 in the Supporting Information); 2 therefore has a new topology in the field of M/S/Cu MOFs.

\section{Crystal structure of 3}

The structural study of $\mathbf{3}$ reveals a 3D honeycomb framework constructed by $\left[\mathrm{WS}_{4} \mathrm{Cu}_{3}\right]^{+}$building clusters and 4,4'-pytz ligands (Figures 7a and 7b; selected bond lengths and angles are summarized in Table 4). Each $\left[\mathrm{WS}_{4} \mathrm{Cu}_{3}\right]^{+}$building cluster of 3 consists of a $\left[\mathrm{WS}_{4}\right]^{2-}$ unit linked to three copper atoms, forming a slightly distorted "flywheel” array. In each flywheel-shaped cluster $\left[\mathrm{WS}_{4} \mathrm{Cu}_{3}\right]^{+}$, all $\mathrm{Cu}$ atoms are coordinated by one $\mu_{2}-\mathrm{S}$ atom, one $\mu_{4}$-S atom and two $\mathrm{N}$ atoms of two $4,4^{\prime}$-pytz bridges, forming a tetrahedral coordination geometry (Figure $7 \mathrm{~b}$ ). The $\mathrm{W}$ atom retains the $C_{3 v}$ geometry of the flywheel-shaped cluster $\left[\mathrm{WS}_{4} \mathrm{Cu}_{3}\right]^{+}$, with $\mathrm{S}-\mathrm{W}-\mathrm{S}$ angles ranging from $108.71(5)^{\circ}$ to $110.22(5)^{\circ}$. The Cu- $\mu_{2}-\mathrm{S}$ bond lengths (Cu1-S1 2.284(2) $\AA$ ) are slightly shorter than those of Cu- $\mu_{4}-\mathrm{S}$ (Cu1-S2 2.323(13) $\AA$ ), while $\mathrm{W}-\mu_{2}$-S bond 
lengths (W1-S1, 2.204(2) $\AA$ ) are shorter than those of W- $\mu_{4}-\mathrm{S}$ (W1-S2, 2.295(3) $\AA$ ). The average $\mathrm{Cu}-\mathrm{N}$ length of 3 (2.052(6) A: Table 4) is slightly longer than that of 2 (2.041(9) Å).

Each flywheel-shaped building cluster connects another six equivalent flywheel-shaped units through single 4,4'-pytz bridges in a 6-connected manner (Figure 7b); it is noteworthy that $\mathbf{3}$ is the first 3D MOF based on flywheel-shaped building clusters. Overall, 3 consists of flywheel-shaped clusters [ $\left.\mathrm{WS}_{4} \mathrm{Cu}_{3}\right]^{+}$linked to each other by $4,4^{\prime}$-pytz bridges in the $a b$ plane, building $2 \mathrm{D}(6,3)$ nets as layer, and then these nets stacking along the $b$-axis to afford a 3D pillared-layer architecture supported by ligands 4,4'-pytz as pillar (Figure 8). From a topological perspective, each flywheel-shaped cluster is a 6-connected node and each 4,4'-pytz ligand is a linker; the topology of $\mathbf{3}$ is an unusual 6-connected network with the short vertex symbol $\left(4^{9} \cdot 6^{6}\right)$ (Figure 9), termed an “ACS” topology which is an arrangement for linking trigonal prisms. ${ }^{[17]}$ The 6-connected nodes are significantly removed from the center of the trigonal prisms (red and green planes in Figure 9), resulting in a heavily distorted "ACS" topology; this is due to the different orientations in the tetrahedral coordination for the flywheel-shaped cluster compared to that of the nest-shaped cluster (Figure S4 in Supporting Information). This is the first example of a heavily distorted “ACS” net found in the field of M/S/Cu MOFs. ${ }^{\text {[9d] }}$

\section{Molecular weights}

To characterize the species generated by dissolution of the MOFs 1-3, we determined their molecular weights in DMF solution by gel-permeation chromatography (GPC). ${ }^{[18]}$ The results show that the number-average molecular weight ( $M_{\mathrm{n}}, 5622$ for $\mathbf{1}, 6534$ for $\mathbf{2}$, and 6387 for 3 ) and the weight-average molecular weight $\left(M_{\mathrm{w}}, 5781\right.$ for $\mathbf{1}, 6648$ for 2 , and 6515 for 3) compared to a polystyrene standard are relatively large, which is consistent with all three MOFs retaining significant intercluster connectivity in DMF solution (the authors recognize that polystyrene standards may not be completely adequate for these demonstrably different MOF materials, but are instead likely to represent a lower bound for the 
molecular weights, consistent with some residual framework structure).

\section{Steady-state fluorescence analysis}

As is well known, electron and/or energy transfer can occur between metal clusters and covalently bound chromophore ligands. ${ }^{[19 a-d]}$ In order to probe the excited-state interactions between the 4,4'-pytz ligands and M/S/Cu clusters, the fluorescence spectra of 4,4'-pytz and 1-3 were measured, the results being compared in Figure 10. Upon excitation at $360 \mathrm{~nm}, 4,4^{\prime}$-pytz exhibits emission bands at 408 and $436 \mathrm{~nm}$ that originate from the $S_{1}-S_{0}$ transition. At the same excitation wavelength, 1-3 possess more intense fluorescence emission bands at 408 and $430 \mathrm{~nm}$, the latter peaks of 1-3 being slightly blue-shifted from those of the free $4,4^{\prime}$-pytz ligands due to ligand-to-metal charge transfer. $^{[19 e]}$ The significant fluorescence enhancement is consistent with a strong interaction between the excited state of the 4,4'-pytz chromophore ligands and the $\mathrm{M} / \mathrm{S} / \mathrm{Cu}$ building clusters in 1-3. Possible pathways for the activation of the excited 4,4'-pytz ligands are energy transfer (ET) and photoinduced electron transfer (PET), ${ }^{[20 a]}$ with the 4,4'-pytz ligands acting as electron transporting and energy absorbing antennas when coordinated to the $\mathrm{Mo}(\mathrm{W}) / \mathrm{S} / \mathrm{Cu}$ clusters, and the $\mathrm{Mo}(\mathrm{W}) / \mathrm{S} / \mathrm{Cu}$ clusters acting as electron accepting moieties. ${ }^{[20 \mathrm{~b}, \mathrm{c}]}$

\section{Nonlinear optical properties}

The third-order NLO absorptive and refractive properties of 1-3 were measured by the Z-scan method, ${ }^{[21]}$ results showing that 1-3 have strong effective third-order NLO absorptive and refractive properties, as illustrated in Figures 11-13, respectively. The effective NLO absorptive coefficients $\alpha_{2}$ of $\mathbf{1 - 3}$ were calculated to be $2.78 \times 10^{-10}$, $4.36 \times 10^{-10}$, and $4.60 \times 10^{-10} \mathrm{~m} \mathrm{~W}^{-1}$, respectively. With the measured value of the difference in the normalized transmittance values at the valley and peak positions, the effective NLO refractive indexes $n_{2}$ were calculated to be $1.80 \times 10^{-17}, 3.21 \times 10^{-17}$, and $2.28 \times 10^{-17} \mathrm{~m}^{2} \mathrm{~W}^{-1}$, respectively. In accordance with the observed $\alpha_{2}$ and $n_{2}$ values, the moduli of the effective third-order susceptibilities $\chi^{(3)}$ were calculated to be $1.23 \times 10^{-11}, 2.11 \times 10^{-11}$, and $1.71 \times 10^{-11}$ esu, respectively; the corresponding moduli of the effective second-order hyperpolarizabilities $\gamma$ are $1.08 \times 10^{-29}, 7.25 \times 10^{-29}$, and 
$1.44 \times 10^{-30}$ esu, respectively, and were obtained from $\chi^{(3)}=\gamma N F^{4}$, where $N$ is the number density (concentration) of cluster compound in the sample solution and $F^{4}=$ 3.3 is the local field correction factor of DMF. The effective hyperpolarizability values $\gamma$ correspond to the NLO properties of neat materials. ${ }^{[11 e, 22]}$ The hyperpolarizabilities $\gamma$ of 1-3 are all larger than those of typical clusters with T-/pentanuclear planar “open"-/flywheel-shaped cluster skeletons, ${ }^{[7]}$ indicating that 1-3 are promising candidates for NLO materials.

\section{Effects of the 4,4'-pytz chromophore on the structures and properties}

Structures 1-3 possess diverse building clusters and connectivity, but are constructed from the same tetrazine-based ligands. Three reported clusters $\left\{\left[\mathrm{Bu}_{4} \mathrm{~N}\right]\left[\mathrm{WS}_{4} \mathrm{Cu}_{3}(\mathrm{CN})_{2}\right]\right\}_{n} \quad(\boldsymbol{a}),{ }^{[9 c]} \quad\left\{\left[\mathrm{Et}_{4} \mathrm{~N}\right]_{2}\left[\mathrm{MoS}_{4} \mathrm{Cu}_{4}(\mathrm{CN})_{4}\right]\right\}_{n} \quad(\boldsymbol{b}),{ }^{[23 \mathrm{a}]} \quad$ and $\left\{\left[\mathrm{WS}_{4} \mathrm{Cu}_{3}(\mathrm{dppm})_{3}\right] \cdot \mathrm{Br}\right\} \quad(\boldsymbol{c})^{[23 \mathrm{~b}]}(\mathrm{dppm}=\operatorname{bis}($ diphenylphosphino)methane $)$ were carefully selected for comparison with the structures and properties of 1-3. While $\boldsymbol{a}$ and $\boldsymbol{b}$ are 3D T-/pentanuclear planar “open”-shaped polymeric clusters with 4-connected modes, and $\boldsymbol{c}$ is a OD flywheel-shaped cluster, 1-3 possess 3D 5-/8-/6-connected configurations based on T-/pentanuclear planar “open”-/flywheel-shaped clusters, respectively, due to the participation of the 4,4'-pytz ligands. Though the building units of $\mathbf{1}, \mathbf{2}$, and $\mathbf{3}$ are the same as $\boldsymbol{a}, \boldsymbol{b}$, and $\boldsymbol{c}$, respectively, the connecting ligands and connectivity of 1-3 differ sharply from those of $\boldsymbol{a}$-c. Similarly, the $\gamma$ values (which reflect the integrated third-order NLO properties) of 1-3 are distinct and indeed superior to $\boldsymbol{a}-\boldsymbol{c}$, as shown in Table 5. Introduction of the tetrazine-chromophore-based 4,4'-pytz ligands not only affords novel structures, but also enhances third-order NLO properties.

\section{Density functional theory studies}

The theoretical absorption spectra (with Lorentzian profiles) ${ }^{[24]}$ of 1-3 obtained from TD-DFT/PCM calculations correspond closely to the experimental observations, as displayed in Figure 14. The dipole-allowed vertical excitations of $\mathbf{1}$ are assigned to transitions from lone-pair orbitals, $n$, of $\mathrm{S}$ atoms to $\pi^{*}$ orbitals dominated by the $5 d$ orbital of $\mathrm{W}$ and the $3 p$ orbital of $\mathrm{S}$, as schematically illustrated in Figure 15 . The 
low-energy absorption features of $\mathbf{2}$ are assigned to transitions from $n$ or $d$ orbitals to $\pi^{*}$ orbitals, corresponding to ligand-to-metal (LMCT, Peak 1) and metal-to-ligand (MLCT, Peak 2) charge transfer (Figure 16). The dipole-allowed vertical excitation energies of 3 mainly correspond to ligand-to-ligand charge transfer (LLCT), assigned to transitions from lone-pair orbitals, $n$, of $\mathrm{N}$ and $\mathrm{C}$ atoms to $\pi^{*}$ orbitals of $4,4^{\prime}$-pytz, as displayed in Figure 17. Thus, there is significant diversity in the nature of the low-energy transitions across this series of MOFs.

\section{Conclusions}

In summary, three unusual 3D tetrazine-chromophore-based MOFs have been successfully constructed: 1 possesses the first 5-connected M/S/Cu framework with a new $\left(4^{4} \cdot 6^{6}\right)$ topology, 2 features a novel 3D $\left(4^{20} \cdot 6^{8}\right)$ topological MOF with unique “distorted arch" 4,4'-pytz bridges, and 3 displays the first 3D MOF based on flywheel-shaped $\left[\mathrm{WS}_{4} \mathrm{Cu}_{3}\right]^{+}$building clusters, and a heavily distorted "ACS” topology. The steady-state fluorescence analysis suggests ET and PET between the excited states of the 4,4'-pytz chromophore and the $\mathrm{M} / \mathrm{S} / \mathrm{Cu}$ clusters in 1-3, while Z-scan experiments of 1-3 demonstrate strong third-order NLO properties. The results show that the tetrazine chromophore-based 4,4'-pytz ligands are crucial in the construction of these novel 3D Mo(W)/S/Cu MOFs and the enhancement of third-order NLO properties. The dipole-allowed excitations in the linear absorption spectra of $\mathbf{1}, \mathbf{2}$, and $\mathbf{3}$ are assigned by TD-DFT/PCM calculations to transitions from lone-pair $n$ orbitals to $\pi^{*}$ orbitals, $n$ or $d$ orbitals to $\pi^{*}$ orbitals, and lone-pair $n$ orbitals to $\pi^{*}$ orbitals, respectively. Further studies on the syntheses of new chromophore-based MOFs and the correlation between cluster configurations and NLO properties of MOFs are currently in progress.

\section{Experimental Section}

Materials and Methods. The reactions and manipulations were conducted using standard Schlenk techniques under an atmosphere of argon. The starting materials $\left[\mathrm{E}_{4} \mathrm{~N}\right]_{2}\left[\mathrm{MS}_{4}\right](\mathrm{E}=\mathrm{Et}, \mathrm{H} ; \mathrm{M}=\mathrm{Mo}, \mathrm{W})$ were obtained by literature procedures. ${ }^{[25]}$ Solvents were dried and distilled prior to use, while other chemicals were 
commercially available and used as received. FT-IR spectra were recorded from $\mathrm{KBr}$ pellets in the range $4000-400 \mathrm{~cm}^{-1}$ on a Nicolet Nexus 470 Fourier transform infrared spectrometer. Elemental analyses of carbon, hydrogen and nitrogen were performed on a FLASH EA 1112. Electronic spectra were measured on a Shimadzu UV-3100 spectrophotometer. The powder X-ray diffraction (PXRD) measurements were recorded on a Bruker D8 ADVANCE powder X-ray diffractometer $(\mathrm{Cu} K \alpha=1.5418$ $\AA$ A). Thermogravimetric analyses were performed on a Netzsch STA-449C thermoanalyzer with a $\mathrm{N}_{2}$ purge and a heating rate of $6{ }^{\circ} \mathrm{C} / \mathrm{min}$.

Preparation of $\left\{\left(\mathrm{Et}_{4} \mathrm{~N}\right)\left[\mathrm{WS}_{4} \mathrm{Cu}_{3}(\mathrm{CN})_{2}\left(4^{\prime} 4^{\prime}-\mathrm{pytz}\right)_{0.5}\right]\right\}_{n}$ (1). A mixture of $\left[\mathrm{Et}_{4} \mathrm{~N}\right]_{2}\left[\mathrm{WS}_{4}\right](0.571 \mathrm{~g}, 1.0 \mathrm{mmol})$ and $\mathrm{CuCN}(0.269 \mathrm{~g}, 3.0 \mathrm{mmol})$ in $10 \mathrm{~mL}$ DMF was stirred for $2 \mathrm{~h}$, and the reaction solution was then filtered affording "filtrate A". A solution of 4,4'-pytz (0.472 g, $2.0 \mathrm{mmol})$ dissolved in $10 \mathrm{~mL}$ dichloromethane was transferred to a glass tube, $5 \mathrm{~mL}$ DMF and $3 \mathrm{~mL}$ dichloromethane were separately layered one after the other on the surface of this solution as a buffer, and then the above filtrate A was layered carefully on the buffer layer. The glass tube was sealed and allowed to stand at room temperature $\left(25^{\circ} \mathrm{C}\right)$. After two months, deep-red block crystals of 1 were collected by filtration, washed with ether and dried in air (yield: 0.184 g, $23 \%$ based on W). Anal. Calcd. for $\mathrm{C}_{16} \mathrm{H}_{24} \mathrm{Cu}_{3} \mathrm{~N}_{6} \mathrm{~S}_{4} \mathrm{~W}$ (\%): C 23.93, H 3.01, N 10.46; Found: C 24.01, H 3.02, N 10.49. IR (KBr, $\left.\mathrm{cm}^{-1}\right)$ : 3405 (w), 2124 (s), 1657 (s), 1478 (s), 1394 (s), 1172 (s), 1003 (s), 782 (s), 598 (s), 452 (vs). UV/vis (DMF, $\lambda_{\max } / \mathrm{nm}$, $\left.\varepsilon / 10^{3} \mathrm{~cm}^{-1} \mathrm{~mol}^{-1} \mathrm{dm}^{3}\right): 266$ (3.66), 290 (3.63), 405 (2.61).

Preparation of $\left\{\left[\mathrm{MoS}_{4} \mathrm{Cu}_{4}(\mathrm{CN})_{2}\left(4,4^{\prime} \text {-pytz) }\right)_{2}\right] \cdot \mathrm{CH}_{2} \mathrm{Cl}_{2}\right\}_{n}$ (2). 2 was obtained as dark-red block crystals by a method similar to that of $\mathbf{1}$ except by using $\left[\mathrm{NH}_{4}\right]_{2}\left[\mathrm{MoS}_{4}\right]$ $(0.260 \mathrm{~g}, 1.0 \mathrm{mmol})$ and $\mathrm{CuCN}(0.358 \mathrm{~g}, 4.0 \mathrm{mmol})$ instead of $\left[\mathrm{Et}_{4} \mathrm{~N}\right]_{2}\left[\mathrm{WS}_{4}\right]$ and CuCN (yield: 0.334 g, 31\% based on Mo). Anal. Calcd. for $\mathrm{C}_{26} \mathrm{H}_{18} \mathrm{Cl}_{2} \mathrm{Cu}_{4} \mathrm{MoN}_{14} \mathrm{~S}_{4}$ (\%): C 29.03, H 1.69, N 18.23; Found: C 29.12, H 1.70, N 18.28. IR (KBr, $\left.\mathrm{cm}^{-1}\right)$ : 3445 (w), 2138 (vs), 1663 (s), 1391 (vs), 1213 (s), 921 (s), 830 (s), 727 (s), 599 (vs), 444 (vs). UV/vis (DMF, $\lambda_{\max } / \mathrm{nm}, \varepsilon / 10^{3} \mathrm{~cm}^{-1} \mathrm{~mol}^{-1} \mathrm{dm}^{3}$ ): 275 (14.50), 404 (5.22).

Preparation of $\left\{\left[\mathrm{WS}_{4} \mathrm{Cu}_{3}\left(4,4^{\prime}-\mathbf{p y t z}\right)_{3}\right] \cdot\left[\mathbf{N}(\mathbf{C N})_{2}\right]\right\}_{n}$ (3). 3 was obtained as red 
block crystals by a method similar to that of 1 except by using $\left[\mathrm{NH}_{4}\right]_{2}\left[\mathrm{WS}_{4}\right](0.348 \mathrm{~g}$, $1 \mathrm{mmol})$ and $\mathrm{Cu}\left[\mathrm{N}(\mathrm{CN})_{2}\right](0.389 \mathrm{~g}, 3 \mathrm{mmol})$ instead of $\left[\mathrm{Et}_{4} \mathrm{~N}\right]_{2}\left[\mathrm{WS}_{4}\right]$ and $\mathrm{CuCN}$ (yield: 0.243 g, $19 \%$ based on W). Anal. Calcd. for $\mathrm{C}_{38} \mathrm{H}_{24} \mathrm{Cu}_{3} \mathrm{~N}_{21} \mathrm{~S}_{4} \mathrm{~W}$ (\%): C 35.72, $\mathrm{H}$ 1.89, N 23.03; Found: C 35.85, H 1.90, N 23.11. IR (KBr, $\left.\mathrm{cm}^{-1}\right)$ : 3452 (s), 2160 (s), 1661 (vs), 1505 (s), 1418 (s), 1391 (vs), 1058 (s), 923 (s), 835 (s), 734 (s), 600 (s), 442 (vs). UV/vis (DMF, $\lambda_{\max } / \mathrm{nm}, \varepsilon / 10^{2} \mathrm{~cm}^{-1} \mathrm{~mol}^{-1} \mathrm{dm}^{3}$ ): 272 (2.57), 406 (0.97).

Single-Crystal Structure Determination. Crystals of 1-3 $(0.45 \times 0.24 \times 0.21$ $\mathrm{mm}$ for $\mathbf{1}, 0.26 \times 0.22 \times 0.21 \mathrm{~mm}$ for 2 and $0.35 \times 0.23 \times 0.22 \mathrm{~mm}$ for 3) suitable for single-crystal X-ray analyses were obtained directly from the above preparations. All measurements were made on a Rigaku Saturn 724+ CCD X-ray diffractometer by using graphite monochromated Mo $K \alpha$ radiation $(\lambda=0.71070 \AA)$. Single crystals of 1-3 were mounted with grease at the top of a glass fiber. Cell parameters were refined on all observed reflections by using the program CrystalClear. ${ }^{[26]}$ The collected data were reduced by the program CrystalClear and an absorption correction (multiscan) was applied. The reflection data for 1-3 were also corrected for Lorentz and polarization effects. The crystal structures of 1-3 were solved by direct methods and refined on $F^{2}$ by full-matrix least-squares methods using the SHELXTL software package. ${ }^{[27]}$ All non-hydrogen atoms were refined anisotropically, and some of the disordered atoms were refined isotropically. All hydrogen atoms were placed in geometrically idealized positions and constrained to ride on their parent atoms. After completing the initial structure solution for $\mathbf{2}$ and 3, many diffuse electron density peaks remained in the channels parallel to the $c$ axis. No satisfactory disorder model could be found, and for further refinements, the contributions of the missing solvent $\left(\mathrm{CH}_{2} \mathrm{Cl}_{2}\right)$ for 2 and the anion $\left(\left[\mathrm{N}(\mathrm{CN})_{2}\right]^{-}\right)$for 3 to the diffraction pattern were subtracted from the observed data by the "SQUEEZE" method as implemented in PLATON. ${ }^{[28]}$ The existence of the solvent molecules $\left(\mathrm{CH}_{2} \mathrm{Cl}_{2}\right)$ and the anions $\left(\left[\mathrm{N}(\mathrm{CN})_{2}\right]^{-}\right)$have also been confirmed by thermogravimetric analysis (Supporting Information, Figure S2), elemental analysis and infrared spectroscopic measurements on 2 and 3. A summary of the key crystallographic information and selected bond 
lengths and bond angles for 1-3 are listed in Tables 1-4, respectively. More detailed crystallographic data has been given in their cif files. CCDC-868775 (1), CCDC-868773 (2), and CCDC-868774 (3) contain the supplementary crystallographic data for this paper. These data can be obtained free of charge from the Cambridge Crystallographic Data Centre via www.ccdc.cam.ac.uk/data_request/cif.

Molecular Weight Measurements. The molecular weight and molecular weight distribution of the MOFs 1-3 were determined at $40{ }^{\circ} \mathrm{C}$ with Gel Permeation Chromatography (Waters Associates Model HPLC/GPC 515 liquid chromatograph, equipped with a refractive index detector, $\mu$-Styragel columns and calibrated with monodisperse polystyrene standards ranging from 580 to 390000 in molecular weight), ${ }^{[29]}$ using DMF as eluent and a flow rate of $1.0 \mathrm{~mL} \mathrm{~min}{ }^{-1}$.

Steady-State Fluorescence Measurements. Steady-state fluorescence spectra were measured on a PTI QM 40 spectrofluorometer; samples were dissolved in chromatographically pure DMF, filtered, and the solutions transferred to a long quartz cell, which was then capped and deoxygenated by bubbling with $\mathrm{N}_{2}$ before measurement.

Nonlinear Optical Measurements. The third-order nonlinear absorptive and refractive properties of $\mathbf{1 - 3}$ as $4.70 \times 10^{-4}(\mathbf{1}), 1.15 \times 10^{-4}(2)$, and $4.89 \times 10^{-5}(3) \mathrm{mol}$ $\mathrm{dm}^{-3}$ DMF solutions were measured with linearly polarized $5 \mathrm{~ns}$ pulses at $532 \mathrm{~nm}$, generated from a Q-switched frequency-doubled Nd:YAG laser, by performing Z-scan measurements. ${ }^{[21]}$ 1-3 are stable toward air and laser light under the experimental conditions. The spatial profiles of the optical pulses were of nearly Gaussian transverse mode. The pulsed laser was focused on the sample cell with a $30 \mathrm{~cm}$ focal length mirror. The spot radius of the laser beam was measured to be $55 \mu \mathrm{m}$ (half-width at $1 / \mathrm{e}^{2}$ maximum). The energies of the input and output pulses were measured simultaneously by precision laser detectors (Rjp-735 energy probes) that were linked to a computer by an IEEE interface, ${ }^{[30]}$ while the incident pulse energy was varied by a Newport Com. attenuator. The interval between the laser pulses was chosen to be $1 \mathrm{~s}$ to avoid the influence of thermal and long-term effects. The samples were mounted on a translation 
stage that was controlled by the computer to move along the axis of the incident laser beam (Z-direction). To determine both the sign and magnitude of the nonlinear refraction, a $0.2 \mathrm{~mm}$ diameter aperture was placed in front of the transmission detector, and the transmittance was recorded as a function of the sample position on the $Z$ axis (closed-aperture Z-scan). To measure the nonlinear absorption, the Z-dependent sample transmittance was taken without the aperture (open-aperture Z-scan).

The modulus of the effective third-order susceptibility $\chi^{(3)}$ was calculated from the observed $\alpha_{2}$ and $n_{2}$ values using the following equation: ${ }^{[21,31]}$

$$
\left|\chi^{(3)}\right|=\sqrt{\left(\left|\frac{9 \times 10^{8} \varepsilon_{0} n_{0}^{2} c^{2}}{2 v} \alpha_{2}\right|^{2}+\left|\frac{c n_{0}^{2}}{80 \pi} n_{2}\right|^{2}\right)}
$$

in which $v$ is the frequency of the incident laser light, $n_{0}$ is the linear refractive index of the sample, and $\varepsilon_{0}$ and $c$ are the permittivity and the speed of light in a vacuum, respectively.

DFT and TD-DFT Calculations. Density functional theory (DFT) and time-dependent density functional theory (TD-DFT) calculations were performed to rationalize the experimental absorption spectra of 1-3 in DMF solution. The models for compounds 1-3 were obtained from the experimental single-crystal X-ray diffraction studies. The restricted singlet wave functions for 1-3 in DMF solution (dielectric constant $\varepsilon=36.71$ ) were tested to be stable within the framework of the polarized continuum model (PCM) at the B3LYP/LanL2DZ level. The vertical electronic excitation energies of 1-3 in DMF solutions were then obtained through TD-DFT/PCM calculations. A Lorentzian function was adopted with the spectral line width set to 100 nm. The DFT/PCM and TD-DFT/PCM calculations were performed using the Gaussian 03 program. ${ }^{[32]}$ The calculated theoretical absorption spectra were shifted in order to facilitate comparison with the experimental spectra (Figure 14). There are several reasons for the peak shifts between experimental observation (black lines) and TD-DFT/PCM calculations: (1) the calculated models comprise only a part of the experimental single-crystal X-ray structures; (2) to simulate the effect of solvent on the absorption spectra, the polarized continuum model was employed. In the continuum 
solvent model, the effects of solvent molecules are described in terms of a continuous dielectric constant, rather than the experimental environment; and (3) the significant charge delocalization may lead to inaccuracies in the description of the electronic structure of $\pi$-conjugated systems due to an intrinsic limitation of DFT exchange-correlation functionals. ${ }^{[33]}$

\section{Acknowledgment}

Financial support from the National Natural Science Foundation of China (50925207, 51172100), the Ministry of Science and Technology of China for the International Science Linkages Program (2009DFA50620, 2011DFG52970), the Ministry of Education of China for the Changjiang Innovation Research Team (IRT1064), the Ministry of Education and the State Administration of Foreign Experts

Affairs for the 111 Project (B13025), and Jiangsu Innovation Research Team is gratefully acknowledged. M.G.H. and M.P.C. thank the Australian Research Council for support. 


\section{References}

[1] a) S. T. Zheng, G. Y. Yang, Chem. Soc. Rev. 2012, 41, 7623-7646; b) R. Peng, M. Li, D. Li, Coord. Chem. Rev. 2010, 254, 1-18; c) N. Yoshinari, A. I. Kamiyama, T. Konno, Chem. Eur. J. 2010, 16, 14247-14251; d) X. X. Li, S. T. Zheng, J. Zhang, W. H. Fang, G. Y. Yang, J. M. Clemente-Juan, Chem. Eur. J. 2011, 17, 13032-13043; e) Y. Kang, F. Wang, J. Zhang, X. H. Bu, J. Am. Chem. Soc. 2012, 134, 17881-17884; f) K. Biradha, C. Y. Su, J. J. Vittal, Cryst. Growth Des. 2011, 11, 875-886; g) S. T. Zheng, J. Zhang, G. Y. Yang, Angew. Chem. 2008, 120, 3973-3977; Angew. Chem. Int. Ed. Engl. 2008, 47, 3909-3913; h) Z. J. Lin, J. Lü, M. C. Hong, R. Cao, Chem. Soc. Rev. 2014, 43, 5867-5895; i) Z. J. Lin, T. F. Liu, Y. B. Huang, J. Lü, R. Cao, Chem. Eur. J. 2012, 18, 7896-7902.

[2] a) Y. C. Liao, F. L. Liao, W. K. Chang, S. L. Wang, J. Am. Chem. Soc. 2004, 126, 1320-1321; b) X. L. Wang, C. Qin, E. B. Wang, Z. M. Su, Y. G. Li, L. Xu, Angew. Chem. 2006, 118, 7571-7574; Angew. Chem. Int. Ed. Engl. 2006, 45, 7411-7414;

c) Y. Zhang, X. W. He, J. Zhang, P. Y. Feng, Cryst. Growth Des. 2011, 11, 29-32; d) Z. Y. Chen, D. B. Luo, M. P. Kang, Z. E. Lin, Inorg. Chem. 2011, 50, 4674-4676; e) J. J. Zhang, H. J. Zhou, A. Lachgar, Angew. Chem. 2007, 119, 5083-5086; Angew. Chem. Int. Ed. Engl. 2007, 46, 4995-4998; f) X. M. Zhang, J. Lv, F. Ji, H. S. Wu, H. J. Jiao, P. v. R. Schleyer, J. Am. Chem. Soc. 2011, 133, 4788-4790; g) Y. X. Tan, Y. P. He, J. Zhang, Chem. Mater. 2012, 24, 4711-4716.

[3] a) K. Liang, H. G. Zheng, Y. L. Song, M. F. Lappert, Y. Z. Li, X. Q. Xin, Z. X. Huang, J. T. Chen, S. F. Lu, Angew. Chem. 2004, 116, 5900-5903; Angew. Chem. Int. Ed. Engl. 2004, 43, 5776-5779; b) C. Rong, Z. W. Yu, Q. Wang, S. T. Zheng, C. Y. Pan, F. Deng, G. Y. Yang, Inorg. Chem. 2009, 48, 3650-3659; c) X. Chen, H. X. Li, Z. Y. Zhang, W. Zhao, J. P. Lang, B. F. Abrahams, Chem. Commun. 2012, 48, 4480-4482; d) A. Dolbecq, E. Dumas, C. R. Mayer, P. Mialane, Chem. Rev. 2010, 110, 6009-6048.

[4] a) C. Wang, T. Zhang, W. B. Lin, Chem. Rev. 2012, 112, 1084-1104; b) W. D. Cheng, D. S. Wu, J. Shen, S. P. Huang, Z. Xie, H. Zhang, Y. J. Gong, Chem. Eur. J. 
2007, 13, 5151-5159; c) H. W. Hou, Y. L. Wei, Y. L. Song, Y. T. Fan, Y. Zhu, Inorg. Chem. 2004, 43, 1323-1327; d) J. C. Yu, Y. J. Cui, C. D. Wu, Y. Yang, Z. Y. Wang, M. O'Keeffe, B. L. Chen, G. D. Qian, Angew. Chem. 2012, 124, 10694-10697; Angew. Chem. Int. Ed. Engl. 2012, 51, 10542-10545.

[5] a) C. Zhang, Y. Cao, J. F. Zhang, S. C. Meng, T. Matsumoto, Y. L. Song, J. Ma, Z. X. Chen, K. Tatsumi, M. G. Humphrey, Adv. Mater. 2008, 20, 1870-1875; b) W. H. Zhang, Y. L. Song, Y. Zhang, J. P. Lang, Cryst. Growth Des. 2008, 8, 253-258; c) X. Chen, H. X. Li, Z. Y. Zhang, C. Xu, K. P. Hou, L. K. Zhou, J. P. Lang, Z. R. Sun, CrystEngComm 2012, 14, 4027-4033.

[6] a) C. Zhang, Y. L. Song, F. E. Kühn, Y. Xu, X. Q. Xin, H. K. Fun, W. A. Herrmann, Eur. J. Inorg. Chem. 2002, 55-64; b) H. W. Hou, Y. L. Wei, Y. L. Song, L. W. Mi, M. S. Tang, L. K. Li, Y. T. Fan, Angew. Chem. 2005, 117, 6221-6228; Angew. Chem. Int. Ed. Engl. 2005, 44, 6067-6074; c) J. H. Li, J. F. Zhang, M. G. Humphrey, C. Zhang, Eur. J. Inorg. Chem. 2013, 328-346.

[7] a) C. Zhang, Y. L. Song, X. Wang, Coord. Chem. Rev. 2007, 251, 111-141; b) Y. Y. Niu, H. G. Zheng, H. W. Hou, X. Q. Xin, Coord. Chem. Rev. 2004, 248, 169-183; c) C. Zhang, G. C. Jin, J. X. Chen, X. Q. Xin, K. P. Qian, Coord. Chem. Rev. 2001, 213, 51-60; d) H. W. Hou, X. Q. Xin, S. Shi, Coord. Chem. Rev. 1996, 153, 25-56; e) C. Zhang, Y. L. Song, B. M. Fung, Z. L. Xue, X. Q. Xin, Chem. Commun. 2001, 843-844.

[8] a) L. Song, J. R. Li, P. Lin, Z. H. Li, T. Li, S. W. Du, X. T.Wu, Inorg. Chem. 2006, 45, 10155-10161; b) Y. Han, Z. H. Zhang, Y. Y. Liu, Y. Y. Niu, D. G. Ding, B. L. Wu, H. W. Hou, Y. T. Fan, Cryst. Growth Des. 2011, 11, 3448-3455; c) Z. Z. Lu, R. Zhang, Z. R. Pan, Y. Z. Li, Z. J. Guo, H. G. Zheng, Chem. Eur. J. 2012, 18, 2812-2824; d) X. Q. Yao, Z. R. Pan, J. S. Hu, Y. Z. Li, Z. J. Guo, H. G. Zheng, Chem. Commun. 2011, 47, 10049-10051.

[9] a) Y. Cai, Y. Wang, Y. Z. Li, X. S. Wang, X. Q. Xin, C. M. Liu, H. G. Zheng, Inorg. Chem. 2005, 44, 9128-9130; b) K. Liang, H. G. Zheng, Y. L. Song, Y. Z. Li, X. Q. Xin, Cryst. Growth Des. 2007, 7, 373-376; c) J. F. Zhang, Y. L. Song, J. Y. Yang, M. G. Humphrey, C. Zhang, Cryst. Growth Des. 2008, 8, 387-390; d) J. 
F. Zhang, S. C. Meng, Y. L. Song, Y. M. Zhou, Y. Cao, J. H. Li, H. J. Zhao, J. C. Hu, J. H. Wu, M. G. Humphrey, C. Zhang, Cryst. Growth Des. 2011, 11, 100-109; e) Y. J. Huang, Y. L. Song, Y. Chen, H. X. Li, Y. Zhang, J. P. Lang, Dalton Trans. 2009, 1411-1421.

[10]a) J. Song, Z. Luo, D. K. Britt, H. Furukawa, O. M. Yaghi, K. I. Hardcastle, C. L. Hill, J. Am. Chem. Soc. 2011, 133, 16839-16846; b) A. C. Sudik, A. P. Côté, A. G. Wong Foy, M. O'Keeffe, O. M. Yaghi, Angew. Chem. 2006, 118, 2590-2595; Angew. Chem. Int. Ed. Engl. 2006, 45, 2528-2533; c) M. Eddaoudi, D. B. Moler, H. L. Li, B. L. Chen, T. M. Reineke, M. O'Keeffe, O. M. Yaghi, Acc. Chem. Res. 2001, 34, 319-330; d) M. O’Keeffe, M. A. Peskov, S. J. Ramsden, O. M. Yaghi, Acc. Chem. Res. 2008, 41, 1782-1789; e) R. Banerjee, H. Furukawa, D. Britt, C. Knobler, M. O’Keeffe, O. M. Yaghi, J. Am. Chem. Soc. 2009, 131, 3875-3877; f) R. J. Hill, D. L. Long, N. R. Champness, P. Hubberstey, M. Schröder, Acc. Chem. Res. 2005, 38, 337-350; g) Q. W. Li, W. Y. Zhang, O. S. Miljanic, C. B. Knobler, J. F. Stoddart, O. M. Yaghi, Chem. Commun. 2010, 46, 380-382; h) N. W. Ockwig, O. Delgado Friedrichs, M. O'Keeffe, O. M. Yaghi, Acc. Chem. Res. 2005, 38, 176-182; i) P. J. Steel, Acc. Chem. Res. 2005, 38, 243-250.

[11]a) B. Esembeson, M. L. Scimeca, T. Michinobu, F. Diederich, I. Biaggio, Adv. Mater. 2008, 20, 4584-4587; b) R. R. Tykwinski, U. Gubler, R. E. Martin, F. Diederich, C. Bosshard, P. Günter, J. Phys. Chem. B 1998, 102, 4451-4465; c) F. Cherioux, P. Audebert, Chem. Mater. 1997, 9, 2921-2927; d) J. M. Hales, J. Matichak, S. Barlow, S. Ohira, K. Yesudas, Science 2010, 327, 1485-1488; d) B. J. Coe, S. P. Foxon, M. Helliwell, D. Rusanova, B. S. Brunschwig, K. Clays, G. Depotter, M. Nyk, M. Samoc, D. Wawrzynczyk, J. Garín, J. Ordun, Chem. Eur. J. 2013, 19, 6613-6629.

[12]a) R. M. Hochstrasser, D. S. King, A. B. Smith, J. Am. Chem. Soc. 1977, 99, 3923-3933; b) Q. Zhou, P. Audebert, G. Clavier, R. Méallet-Renault, F. Miomandre, Z. Shaukat, T. Vu, J. Tang, J. Phys. Chem. C 2011, 115, 21899-21906.

[13]a) C. X. She, S. J. Lee, J. E. McGarrah, J. V. Weis, M. R. Wasielewski, H. N. Chen, 
G. C. Schatz, M. A. Ratner, J. T. Hupp, Chem. Commun. 2010, 46, 547-549; b) M. Xue, S. Q. Ma, Z. Jin, R. M. Schaffino, G. S. Zhu, E. B. Lobkovsky, S. L. Qiu, B. L. Chen, Inorg. Chem. 2008, 47, 6825-6828; c) P. H. Dinolfo, M. E. Williams, C. L. Stern, J. T. Hupp, J. Am. Chem. Soc. 2004, 126, 12989-13001; d) M. A. Withersby, A. J. Blake, N. R. Champness, P. Hubberstey, W. S. Li, M. Schroder, Angew. Chem. 1997, 34, 2421-2423; Angew. Chem. Int. Ed. Engl. 1997, 36, 2327-2329; e) N. S. Oxtoby, A. J. Blake, N. R. Champness, C. Wilson, CrystEngComm 2003, 5, 82-86.

[14]a) V. Guillerm, D. Kim, J. F. Eubank, R. Luebke, X. F. Liu, K. Adil, M. S. Lah, M. Eddaoudi, Chem. Soc. Rev. 2014, 43, 6141-6172; b) M. K. Sharma, I. Senkovska, S. Kaskel, P. K. Bharadwaj, Inorg. Chem. 2011, 50, 539-544.

[15]Y. B. Zhang, H. L. Zhou, R. B. Lin, C. Zhang, J. B. Lin, J. P. Zhang, X. M. Chen, Nat. Commun. 2012, 3, 642.

[16]W. H. Zhang, J. P. Lang, Y. Zhang, B. F. Abrahams, Cryst. Growth Des. 2008, 8, 399-401.

[17]a) A. Schoedel, L. Wojtas, S. P. Kelley, R. D. Rogers, M. Eddaoudi, M. J. Zaworotko, Angew. Chem. 2011, 123, 11623-11626; Angew. Chem. Int. Ed. Engl. 2011, 50, 11421-11424; b) A. C. Sudik, A. P. Côté, O. M. Yaghi, Inorg. Chem. 2005, 44, 2998-3000; c) L. Carlucci, G. Ciani, S. Maggini, D. M. Proserpio, M. Visconti, Chem. Eur. J. 2010, 16, 12328-12341.

[18]a) H. Xu, Y. L. Song, L. W. Mi, H. W. Hou, M. S. Tang, Y. L. Sang, Y. T. Fan, Y. Pan, Dalton Trans. 2006, 838-845; b) Y. Y. Niu, Y. L. Song, H. W. Hou, Y. Zhu, Inorg. Chem. 2005, 44, 2553-2559; c) J. H. Li, S. C. Meng, J. F. Zhang, Y. L. Song, Z. P. Huang, H. J. Zhao, H. Y. Wei, W. J. Huang, M. P. Cifuentes, M. G. Humphrey, C. Zhang, CrystEngComm 2012, 14, 2787-2796.

[19]a) A. Gaiduk, M. Yorulmaz, P. V. Ruijgrok, M. Orrit, Science 2010, 330, 353-356;

b) W. Kaim, Coord. Chem. Rev. 2011, 255, 2503-2513; c) C. Y. Lee, J. K. Jang, C. H. Kim, J. Jung, B. K. Park, J. Park, W. Choi, Y. K. Han, T. Joo, J. T. Park, Chem. Eur. J. 2010, 16, 5586-5599; d) B. D. Yuhas, A. L. Smeigh, A. P. Douvalis, M. R. Wasielewski, M. G. Kanatzidis, J. Am. Chem. Soc. 2012, 134, 10353-10356; e) Y. 
J Cui, Y. F. Yue, G. D. Qian, B. L. Chen, Chem. Rev. 2012, 112, 1126-1162.

[20]a) Y. F. Xu, Z. B. Liu, X. L. Zhang, Y. Wang, J. G. Tian, Y. Huang, Y. F. Ma, X. Y. Zhang, Y. S. Chen, Adv. Mater. 2009, 21, 1275-1279; b) J. H. Zhu, Y. X. Li, Y. Chen, J. Wang, B. Zhang, J. J. Zhang, W. J. Blau, Carbon 2011, 49, 1900-1905; c) Z. Guo, F. Du, D. M. Ren, Y. S Chen, J. Y. Zheng, Z. B Liu, J. G. Tian, J. Mater. Chem. 2006, 16, 3021-3030.

[21]M. Sheik-Bahae, A. A. Said, T. H. Wei, D. J. Hagan, E. W. Van Stryland, IEEE J. Quantum Electron. 1990, 26, 760-769.

[22]a) C. Zhang, Y. L. Song, G. C. Jin, G. Y. Feng, Y. X. Wang, S. S. S. Rag, H. K. Fun, X. Q. Xin, J. Chem. Soc. Dalton Trans. 2000, 1317-1323; b) Z. R. Chen, H. W. Hou, X. Q. Xin, K. B. Yu, S. Shi, J. Phys. Chem. 1995, 99, 8717-8721; c) L. Yang, R. Dorsinville, Q. Z. Wang, P. X. Ye, R. R. Alfano, R. Zamboni, C. Taliani, Opt. Lett. 1992, 17, 323-325.

[23]a) C. Zhang, Y. L. Song, Y. Xu, H. K. Fun, G. Y. Fang, Y. X. Wang, X. Q. Xin, J. Chem. Soc. Dalton Trans. 2000, 2823-2829; b) J. P. Lang, K. Tatsumi, Inorg. Chem. 1998, 37, 6308-6316.

[24]D. C. Harris, M. D. Bertolucci, Symmetry and Spectroscopy: An Introduction to Vibrational and Electronic Spectroscopy; Oxford University Press, New York, 1978, pp 307-419.

[25]J. W. McDonald, G. D. Frieson, L. D. Rosenhein, W. E. Newton, Inorg. Chim. Acta 1983, 72, 205-210.

[26]CrystalClear Version 1.3.5. Rigaku Corporation, Tokyo, Japan 2002.

[27]G. M. Sheldrick, SHELXS 97 and SHELXL 97, Programs for Crystal Structure Refinement, University of Göttingen, Germany 1997.

[28]a) A. L. Spek, J. Appl. Crystallogr. 2003, 36, 7-11; b) P. van der Sluis, A. L. Spek, Acta Crystallogr. Sect. A 1990, 46, 194-201.

[29] M. D. Randles, N. T. Lucas, M. P. Cifuentes, M. G. Humphrey, M. K. Smith, A. C. Willis, M. Samoc, Macromolecules 2007, 40, 7807-7818.

[30]M. Sheik-Bahae, D. C. Hutchings, D. J. Hagan, E. W. Van Stryland, IEEE J. Quantum Electron. 1991, 27, 1296-1309. 
[31]H. W. Hou, H. G. Ang, S. G. Ang, Y. T. Fan, M. K. M. Low, W. Ji, Y. W. Lee, Phys. Chem. Chem. Phys. 1999, 1, 3145-3149.

[32]M. J. Frisch, et al. Gaussian 03; Revision D.01; Gaussian Inc, Wallingford, CT, 2004. For the complete list of authors, see Supporting Information.

[33]a) M. van Faassen, P. L. de Boeij, R. van Leeuwen, J. A. Berger, J. G. Snijders, Phys. Rev. Lett. 2002, 88, 186401-186404; b) X. Lin, J. Li, E. Smela, S. Yip, Int. J. Quantum Chem. 2005, 102, 980-985. 
Scheme Caption:

Scheme 1. Syntheses of 1-3 from reactions of $\left[\mathrm{MS}_{4}\right]^{2-}(\mathrm{M}=\mathrm{Mo}, \mathrm{W})$ and $\mathrm{CuCN} /$ $\mathrm{Cu}\left[\mathrm{N}(\mathrm{CN})_{2}\right]$ with 4,4'-pytz ligands. 


\section{Figure Captions:}

Figure 1. a) Packing diagram of $\mathbf{1}$ along the $a$-axis (all hydrogen atoms have been omitted for clarity); b) coordination environment of the T-shaped cluster $\left[\mathrm{WS}_{4} \mathrm{Cu}_{3}\right]^{+}$in $\mathbf{1}$, demonstrating the 5-connected manner.

Figure 2. Top: Packing diagram of 1 along the $c$-axis. Bottom: The 2D $(4,4)$ nets from the 3D framework.

Figure 3. The $\left(4^{4} \cdot 6^{6}\right)$ topology of $\mathbf{1}$; the yellow balls, blue sticks and pink sticks represent the $\left[\mathrm{WS}_{4} \mathrm{Cu}_{3}\right]^{+}$nodes, and the $\mathrm{CN}^{-}$and 4,4'-pytz bridges, respectively.

Figure 4. a) Packing diagram of 2 along the $c$-axis (all hydrogen atoms have been omitted for clarity); b) coordination environment of the pentanuclear planar “open”-shaped cluster $\left[\mathrm{MoS}_{4} \mathrm{Cu}_{4}\right]^{2+}$ in 2, linked by single $\mathrm{CN}^{-}$and “distorted arch" 4,4'-pytz bridges in the $a b$ plane; c) distortions of the 4,4'-pytz bridges are defined as the ratio $(\delta)$ of arc height over chord length of the ligands (the 4,4'-pytz backbones are simplified as red solid lines for clarity).

Figure 5. Top: Packing diagram of 2 along the $b$-axis. Bottom: The $2 \mathrm{D}(4,4)$ nets from the $3 \mathrm{D}$ framework.

Figure 6. The 8-connected $\left(4^{20} \cdot 6^{8}\right)$ topology of 2 ; the yellow spheres represent the $\left[\mathrm{MoS}_{4} \mathrm{Cu}_{4}\right]^{2+}$ cores, while the bridging $\mathrm{CN}^{-}$and 4,4'-pytz ligands are indicated by blue and pink sticks, respectively.

Figure 7. a) Packing diagram of 3 along the $c$-axis, showing the honeycomb channels (all hydrogen atoms have been omitted for clarity); b) coordination environment of the flywheel-shaped cluster $\left[\mathrm{WS}_{4} \mathrm{Cu}_{3}\right]^{+}$in 3 , showing the 6-connected mode.

Figure 8. Top: Packing diagram of $\mathbf{3}$ along the $b$-axis. Middle and bottom left: The 2D $(6,3)$ nets from the 3D framework. Bottom right: The building units of the flywheel-shaped clusters from the 2D $(6,3)$ nets.

Figure 9. The heavily distorted “ACS” topology of $\mathbf{3}$ with nodes highlighted in pink emphasizing the trigonal prismatic geometries (red and green planes); the 
yellow balls and pink sticks represent the flywheel-shaped building clusters [WS $\left.{ }_{4} \mathrm{Cu}_{3}\right]^{+}$and single $4,4^{\prime}$-pytz bridges, respectively.

Figure 10. Fluorescence spectra of 4,4'-pytz and 1-3 in DMF, following excitation at $360 \mathrm{~nm}$.

Figure 11. Z-scan measurement of 1 in $4.70 \times 10^{-4} \mathrm{~mol} \mathrm{dm}^{-3} \mathrm{DMF}$ solution at $532 \mathrm{~nm}$. (a) Data collected under the open-aperture configuration. (b) Data obtained by dividing the normalized Z-scan data obtained under the closed-aperture configuration by the normalized $Z$-scan data in (a).

Figure 12. Z-scan measurement of 2 in $1.15 \times 10^{-4} \mathrm{~mol} \mathrm{dm}^{-3} \mathrm{DMF}$ solution at $532 \mathrm{~nm}$. (a) Data collected under the open-aperture configuration. (b) Data obtained by dividing the normalized $Z$-scan data obtained under the closed-aperture configuration by the normalized Z-scan data in (a).

Figure 13. Z-scan measurement of 3 in $4.89 \times 10^{-5} \mathrm{~mol} \mathrm{dm}^{-3} \mathrm{DMF}$ solution at $532 \mathrm{~nm}$. (a) Data collected under the open-aperture configuration. (b) Data obtained by dividing the normalized $Z$-scan data obtained under the closed-aperture configuration by the normalized Z-scan data in (a).

Figure 14. Absorption spectra of (a) 1, (b) 2, and (c) 3 (in DMF) obtained from experimental observation (black lines) and TD-DFT/PCM calculations (blue lines). For the latter, a Lorentzian function has been adopted with the spectral line width set to $100 \mathrm{~nm}$. The theoretical spectra are (a) shifted to shorter wavelength by $150 \mathrm{~nm}(\mathbf{1})$ and $(\mathrm{b}, \mathrm{c})$ shifted to longer wavelength by $73 \mathrm{~nm}$ (2) and $110 \mathrm{~nm}$ (3), in comparison with their TD-DFT excitation energies.

Figure 15. Absorption peak assignment for $\mathbf{1}$ (in DMF). The molecular orbitals are obtained through TD-DFT/PCM calculations at the B3LYP/LanL2DZ level.

Figure 16. Absorption band assignments (Peak 1 and Peak 2) for 2. The molecular orbitals are obtained through TD-DFT/PCM calculations at the B3LYP/LanL2DZ level.

Figure 17. Absorption band assignments (Peak 1 and Peak 2) for 3 . The molecular 
orbitals are obtained through TD-DFT/PCM calculations at the B3LYP/LanL2DZ level. 


\section{Table Captions:}

Table 1. Crystallographic and structure refinement data for 1-3.

Table 2. Selected bond lengths ( $\AA$ ) and angles $\left(^{\circ}\right)$ for $\mathbf{1}$.

Table 3. Selected bond lengths $(\AA)$ and angles $\left(^{\circ}\right)$ for $\mathbf{2}$.

Table 4. Selected bond lengths ( $\AA$ ) and angles $\left(^{\circ}\right)$ for $\mathbf{3}$.

Table 5. Structures and NLO properties of 1-3 compared with $\boldsymbol{a}$-c. 
Scheme 1. Syntheses of 1-3 from reactions of $\left[\mathrm{MS}_{4}\right]^{2-}(\mathrm{M}=\mathrm{Mo}, \mathrm{W})$ and $\mathrm{CuCN} /$ $\mathrm{Cu}\left[\mathrm{N}(\mathrm{CN})_{2}\right]$ with 4,4'-pytz ligands. 
Figure 1. a) Packing diagram of 1 along the $a$-axis (all hydrogen atoms have been omitted for clarity); b) coordination environment of the T-shaped cluster $\left[\mathrm{WS}_{4} \mathrm{Cu}_{3}\right]^{+}$in $\mathbf{1}$, demonstrating the 5-connected manner. 
Figure 2. Top: Packing diagram of 1 along the $c$-axis. Bottom: The 2D $(4,4)$ nets from the 3D framework. 
Figure 3. The $\left(4^{4} \cdot 6^{6}\right)$ topology of 1 ; the yellow balls, blue sticks and pink sticks represent the $\left[\mathrm{WS}_{4} \mathrm{Cu}_{3}\right]^{+}$nodes, and the $\mathrm{CN}^{-}$and $4,4^{\prime}$-pytz bridges, respectively. 
Figure 4. a) Packing diagram of 2 along the $c$-axis (all hydrogen atoms have been omitted for clarity); b) coordination environment of the pentanuclear planar “open”-shaped cluster $\left[\mathrm{MoS}_{4} \mathrm{Cu}_{4}\right]^{2+}$ in 2, linked by single $\mathrm{CN}^{-}$and "distorted arch" 4,4'-pytz bridges in the $a b$ plane; c) distortions of the 4,4'-pytz bridges are defined as the ratio $(\delta)$ of arc height over chord length of the ligands (the 4,4'-pytz backbones are simplified as red solid lines for clarity). 
Figure 5. Top: Packing diagram of 2 along the $b$-axis. Bottom: The 2D $(4,4)$ nets from the 3D framework. 
Figure 6. The 8-connected $\left(4^{20} \cdot 6^{8}\right)$ topology of 2; the yellow spheres represent the $\left[\mathrm{MoS}_{4} \mathrm{Cu}_{4}\right]^{2+}$ cores, while the bridging $\mathrm{CN}^{-}$and 4,4'-pytz ligands are indicated by blue and pink sticks, respectively. 
Figure 7. a) Packing diagram of 3 along the $c$-axis, showing the honeycomb channels (all hydrogen atoms have been omitted for clarity); b) coordination environment of the flywheel-shaped cluster $\left[\mathrm{WS}_{4} \mathrm{Cu}_{3}\right]^{+}$in 3 , showing the 6-connected mode. 
Figure 8. Top: Packing diagram of $\mathbf{3}$ along the $b$-axis. Middle and bottom left: The 2D $(6,3)$ nets from the 3D framework. Bottom right: The building units of the flywheel-shaped clusters from the 2D $(6,3)$ nets. 
Figure 9. The heavily distorted “ACS” topology of $\mathbf{3}$ with nodes highlighted in pink emphasizing the trigonal prismatic geometries (red and green planes); the yellow balls and pink sticks represent the flywheel-shaped building clusters $\left[\mathrm{WS}_{4} \mathrm{Cu}_{3}\right]^{+}$and single 4,4'-pytz bridges, respectively. 
Figure 10. Fluorescence spectra of 4,4'-pytz and 1-3 in DMF, following excitation at $360 \mathrm{~nm}$. 
Figure 11. Z-scan measurement of 1 in $4.70 \times 10^{-4} \mathrm{~mol} \mathrm{dm}^{-3} \mathrm{DMF}$ solution at $532 \mathrm{~nm}$. (a) Data collected under the open-aperture configuration. (b) Data obtained by dividing the normalized Z-scan data obtained under the closed-aperture configuration by the normalized $Z$-scan data in (a). 
Figure 12. Z-scan measurement of 2 in $1.15 \times 10^{-4} \mathrm{~mol} \mathrm{dm}^{-3}$ DMF solution at $532 \mathrm{~nm}$. (a) Data collected under the open-aperture configuration. (b) Data obtained by dividing the normalized Z-scan data obtained under the closed-aperture configuration by the normalized $Z$-scan data in (a). 
Figure 13. Z-scan measurement of 3 in $4.89 \times 10^{-5} \mathrm{~mol} \mathrm{dm}^{-3} \mathrm{DMF}$ solution at $532 \mathrm{~nm}$. (a) Data collected under the open-aperture configuration. (b) Data obtained by dividing the normalized Z-scan data obtained under the closed-aperture configuration by the normalized $Z$-scan data in (a). 
Figure 14. Absorption spectra of (a) 1, (b) 2, and (c) 3 (in DMF) obtained from experimental observation (black lines) and TD-DFT/PCM calculations (blue lines). For the latter, a Lorentzian function has been adopted with the spectral line width set to $100 \mathrm{~nm}$. The theoretical spectra are (a) shifted to shorter wavelength by $150 \mathrm{~nm}$ (1) and (b,c) shifted to longer wavelength by $73 \mathrm{~nm}(2)$ and $110 \mathrm{~nm}$ (3), in comparison with their TD-DFT excitation energies. 
Figure 15. Absorption peak assignment for 1 (in DMF). The molecular orbitals are obtained through TD-DFT/PCM calculations at the B3LYP/LanL2DZ level. 
Figure 16. Absorption band assignments (Peak 1 and Peak 2) for 2. The molecular orbitals are obtained through TD-DFT/PCM calculations at the B3LYP/LanL2DZ level. 
Figure 17. Absorption band assignments (Peak 1 and Peak 2) for 3. The molecular orbitals are obtained through TD-DFT/PCM calculations at the B3LYP/LanL2DZ level. 
Table 1. Crystallographic and structure refinement data for 1-3.

\begin{tabular}{|c|c|c|c|}
\hline Crystal parameters & 1 & 2 & 3 \\
\hline Molecular formula & $\mathrm{C}_{16} \mathrm{H}_{24} \mathrm{Cu}_{3} \mathrm{~N}_{6} \mathrm{~S}_{4} \mathrm{~W}$ & $\mathrm{C}_{26} \mathrm{H}_{18} \mathrm{Cl}_{2} \mathrm{Cu}_{4} \mathrm{MoN}_{14} \mathrm{~S}_{4}$ & $\mathrm{C}_{38} \mathrm{H}_{24} \mathrm{Cu}_{3} \mathrm{~N}_{21} \mathrm{~S}_{4} \mathrm{~W}$ \\
\hline Formula weight & 803.12 & 1075.86 & 1277.55 \\
\hline Temperature (K) & 293(2) & 293(2) & 293(2) \\
\hline Crystal system & Monoclinic & Tetragonal & Hexagonal \\
\hline Space group & $P 2_{1} / c$ & $I 4_{1} /$ acd & $P-3 c 1$ \\
\hline$a(\AA)$ & $9.2823(19)$ & 13.6570(19) & 20.1599(16) \\
\hline$b(\AA)$ & $14.575(3)$ & 13.6570(19) & 20.1599(16) \\
\hline$c(\AA)$ & 19.371(4) & $53.305(11)$ & 13.555(3) \\
\hline$\alpha\left(^{\circ}\right)$ & 90 & 90 & 90 \\
\hline$\beta\left(^{\circ}\right)$ & $98.05(3)$ & 90 & 90 \\
\hline$\gamma\left({ }^{\circ}\right)$ & 90 & 90 & 120 \\
\hline$V\left(\AA^{3}\right)$ & 2594.9(9) & 9942(3) & 8907(3) \\
\hline$Z$ & 4 & 8 & 4 \\
\hline$\rho_{\text {calc }}\left(\mathrm{g} \mathrm{cm}^{-3}\right)$ & 2.056 & 1.438 & 0.953 \\
\hline$\mu\left(\mathrm{mm}^{-1}\right)$ & 7.181 & 2.236 & 2.117 \\
\hline \multirow[t]{2}{*}{$F(000)$} & 1548 & 4222 & 2495 \\
\hline & $-11 \leq \mathrm{h} \leq 8$ & $-12 \leq \mathrm{h} \leq 17$ & $-32 \leq \mathrm{h} \leq 17$ \\
\hline \multirow[t]{2}{*}{ Limiting indices } & $-14 \leq \mathrm{k} \leq 17$ & $-17 \leq k \leq 13$ & $-32 \leq \mathrm{k} \leq 23$ \\
\hline & $-20 \leq 1 \leq 22$ & $-63 \leq 1 \leq 66$ & $-11 \leq 1 \leq 16$ \\
\hline Reflections collected & 10685 & 12432 & 20235 \\
\hline Unique reflections & 4519 & 2534 & 5382 \\
\hline$R_{\mathrm{int}}$ & 0.0298 & 0.0506 & 0.0977 \\
\hline GOF & 1.017 & 1.192 & 0.958 \\
\hline$R_{1}[I>2 \sigma(I)]$ & 0.0330 & 0.0443 & 0.0651 \\
\hline$w R_{2}[I>2 \sigma(I)]$ & 0.0662 & 0.1287 & 0.1469 \\
\hline$\Delta \rho_{\max } / \Delta \rho_{\min }\left(\mathrm{e} \AA^{-3}\right)$ & $1.208 /-1.412$ & $0.545 /-0.460$ & $0.718 /-1.347$ \\
\hline
\end{tabular}


Table 2. Selected bond lengths ( $\AA$ ) and angles $\left(^{\circ}\right)$ for $\mathbf{1}$.

\begin{tabular}{cccc}
\hline $\multicolumn{5}{c}{\left(\mathrm{Et}_{4} \mathrm{~N}\right)\left[\mathrm{WS}_{4} \mathrm{Cu}_{3}(\mathrm{CN})_{2}\left(4,4^{\prime}-\mathrm{pytz}\right)_{0.5}\right]}_{n}(\mathbf{1})$ & \\
\hline $\mathrm{W}(1)-\mathrm{S}(1)$ & $2.224(16)$ & $\mathrm{W}(1)-\mathrm{S}(2)$ & $2.259(15)$ \\
$\mathrm{W}(1)-\mathrm{S}(3)$ & $2.183(16)$ & $\mathrm{W}(1)-\mathrm{S}(4)$ & $2.215(15)$ \\
$\mathrm{Cu}(1)-\mathrm{S}(1)$ & $2.304(16)$ & $\mathrm{Cu}(1)-\mathrm{S}(2)$ & $2.301(19)$ \\
$\mathrm{Cu}(2)-\mathrm{S}(1)$ & $2.3459(16)$ & $\mathrm{Cu}(2)-\mathrm{S}(3)$ & $2.301(19)$ \\
$\mathrm{Cu}(3)-\mathrm{S}(2)$ & $2.248(16)$ & $\mathrm{Cu}(3)-\mathrm{S}(4)$ & $2.226(18)$ \\
$\mathrm{W}(1)-\mathrm{Cu}(1)$ & $2.727(9)$ & $\mathrm{W}(1)-\mathrm{Cu}(2)$ & $2.724(9)$ \\
$\mathrm{W}(1)-\mathrm{Cu}(3)$ & $2.640(8)$ & $\mathrm{Cu}(1)-\mathrm{C}(1)$ & $1.926(6)$ \\
$\mathrm{Cu}(1)-\mathrm{N}(1)$ & $2.186(4)$ & $\mathrm{Cu}(2)-\mathrm{N}(2)$ & $1.958(5)$ \\
$\mathrm{Cu}(2)-\mathrm{N}(3) \# 3$ & $2.023(5)$ & $\mathrm{Cu}(3)-\mathrm{C}(2) \# 2$ & $1.879(6)$ \\
$\mathrm{Cu}(3)-\mathrm{W}(1)-\mathrm{Cu}(2)$ & $177.24(2)$ & $\mathrm{Cu}(2)-\mathrm{W}(1)-\mathrm{Cu}(1)$ & $90.79(3)$ \\
$\mathrm{Cu}(3)-\mathrm{W}(1)-\mathrm{Cu}(1)$ & $91.04(3)$ & $\mathrm{S}(4)-\mathrm{W}(1)-\mathrm{S}(2)$ & $107.67(6)$ \\
$\mathrm{S}(3)-\mathrm{W}(1)-\mathrm{S}(4)$ & $111.26(6)$ & $\mathrm{S}(3)-\mathrm{W}(1)-\mathrm{S}(2)$ & $109.96(7)$ \\
$\mathrm{S}(3)-\mathrm{W}(1)-\mathrm{S}(1)$ & $109.87(6)$ & $\mathrm{S}(4)-\mathrm{W}(1)-\mathrm{S}(1)$ & $109.82(6)$ \\
$\mathrm{S}(1)-\mathrm{W}(1)-\mathrm{S}(2)$ & $108.18(6)$ & & \\
Symmetry transformations used to generate & & \\
$\# 1-\mathrm{x}, \mathrm{y}+1 / 2,-\mathrm{z}+1 / 2 ;$ \#2 x, - y + 1/2, z + 1/2; \#3 - x, y-1/2, - z + 1/2; \#4 - x + 1, - & \\
$\mathrm{y},-\mathrm{z}$ \# \#5 x, - y + 1/2, z - 1/2. & & & \\
\hline
\end{tabular}


Table 3. Selected bond lengths ( $\AA$ ) and angles $\left(^{\circ}\right)$ for 2.

\begin{tabular}{cccc}
\hline $\multicolumn{4}{c}{\left[\mathrm{MoS}_{4} \mathrm{Cu}_{4}(\mathrm{CN})_{2}\left(4,4^{\prime}-\mathrm{pytz}\right)_{2}\right] \cdot \mathrm{CH}_{2} \mathrm{Cl}_{2}}_{n}(2)$ \\
\hline $\mathrm{Mo}(1)-\mathrm{S}(1) \# 1$ & $2.234(11)$ & $\mathrm{Mo}(1)-\mathrm{Cu}(1) \# 1$ & $2.695(6)$ \\
$\mathrm{Cu}(1)-\mathrm{S}(1) \# 1$ & $2.292(13)$ & $\mathrm{Cu}(1)-\mathrm{S}(1)$ & $2.323(13)$ \\
$\mathrm{Cu}(1)-\mathrm{N}(1)$ & $2.171(4)$ & $\mathrm{Cu}(1)-\mathrm{N}(2)$ & $1.912(4)$ \\
$\mathrm{Cu}(1) \# 1-\mathrm{Mo}(1)-\mathrm{Cu}(1) \# 2$ & $164.09(2)$ & $\mathrm{Cu}(1)-\mathrm{Mo}(1)-\mathrm{Cu}(1) \# 3$ & $164.09(2)$ \\
$\mathrm{S}(1) \# 1-\mathrm{Mo}(1)-\mathrm{S}(1) \# 2$ & $112.27(6)$ & $\mathrm{S}(1) \# 1-\mathrm{Mo}(1)-\mathrm{S}(1)$ & $108.09(3)$ \\
$\mathrm{N}(2)-\mathrm{Cu}(1)-\mathrm{S}(1) \# 1$ & $123.23(14)$ & $\mathrm{N}(1)-\mathrm{Cu}(1)-\mathrm{S}(1) \# 1$ & $107.92(11)$ \\
Symmetry transformations used to generate equivalent atoms: & \\
$\# 1 \mathrm{y}-3 / 4,-\mathrm{x}-5 / 4,-\mathrm{z}+1 / 4 ; \# 2-\mathrm{y}-5 / 4, \mathrm{x}+3 / 4,-\mathrm{z}+1 / 4 ; \# 3-\mathrm{x}-2,-\mathrm{y}-1 / 2, \mathrm{z}$. \\
\hline
\end{tabular}


Table 4. Selected bond lengths ( $\AA$ ) and angles $\left(^{\circ}\right)$ for 3.

\begin{tabular}{cccc}
\hline $\multicolumn{4}{c}{\left[\mathrm{WS}_{4} \mathrm{Cu}_{3}\left(4,4^{\prime}-\mathrm{pytz}\right)_{3}\right] \cdot\left[\mathrm{N}(\mathrm{CN})_{2}\right]}_{n}(3)$ \\
\hline $\mathrm{W}(1)-\mathrm{S}(1) \# 1$ & $2.204(2)$ & $\mathrm{W}(1)-\mathrm{S}(2)$ & $2.295(3)$ \\
$\mathrm{W}(1)-\mathrm{Cu}(1) \# 2$ & $2.699(10)$ & $\mathrm{Cu}(1)-\mathrm{S}(1)$ & $2.284(2)$ \\
$\mathrm{Cu}(1)-\mathrm{S}(2)$ & $2.323(13)$ & $\mathrm{Cu}(1)-\mathrm{N}(1)$ & $2.025(6)$ \\
$\mathrm{Cu}(1)-\mathrm{N}(2)$ & $2.079(6)$ & & \\
$\mathrm{S}(1) \# 1-\mathrm{W}(1)-\mathrm{S}(1)$ & $110.22(5)$ & $\mathrm{S}(1) \# 1-\mathrm{W}(1)-\mathrm{S}(2)$ & $108.71(5)$ \\
$\mathrm{N}(1)-\mathrm{Cu}(1)-\mathrm{S}(1)$ & $117.68(18)$ & $\mathrm{N}(2)-\mathrm{Cu}(1)-\mathrm{S}(1)$ & $104.76(19)$ \\
$\mathrm{S}(1)-\mathrm{Cu}(1)-\mathrm{S}(2)$ & $105.06(9)$ & $\mathrm{N}(1)-\mathrm{Cu}(1)-\mathrm{S}(2)$ & $112.42(18)$ \\
Symmetry transformations used to generate equivalent atoms: & \\
$\# 1-\mathrm{y}+1, \mathrm{x}-\mathrm{y}, \mathrm{z} ; \# 2-\mathrm{x}+\mathrm{y}+1,-\mathrm{x}+1, \mathrm{z}$. \\
\hline
\end{tabular}


Table 5. Structures and NLO properties of 1-3 compared with $\boldsymbol{a}$-c.

\begin{tabular}{|c|c|c|c|c|c|c|}
\hline NO. & Molecular formulas & Building units & Ligands & Connectivity & Dimensions and topology & $\gamma(\mathrm{esu})$ \\
\hline 1 & $\left\{\left(\mathrm{Et}_{4} \mathrm{~N}\right)\left[\mathrm{WS}_{4} \mathrm{Cu}_{3}(\mathrm{CN})_{2}\left(4,4^{\prime}-\mathrm{pytz}\right)_{0.5}\right]\right\}_{n}$ & T-shaped & $\mathrm{CN}^{-} / 4,4^{\prime}-$ pytz & 5-connected & $3 \mathrm{D},\left(4^{4} \cdot 6^{6}\right)$ & $1.08 \times 10^{-29}$ \\
\hline$a$ & $\left\{\left[\mathrm{Bu}_{4} \mathrm{~N}\right]\left[\mathrm{WS}_{4} \mathrm{Cu}_{3}(\mathrm{CN})_{2}\right]\right\}_{n}$ & T-shaped & $\mathrm{CN}^{-}$ & 4-connected & 3D, diamondoid & $3.40 \times 10^{-30}$ \\
\hline 2 & $\left\{\left[\mathrm{MoS}_{4} \mathrm{Cu}_{4}(\mathrm{CN})_{2}\left(4,4^{\prime}-\mathrm{pytz}\right)_{2}\right] \cdot \mathrm{CH}_{2} \mathrm{Cl}_{2}\right\}_{n}$ & $\begin{array}{l}\text { pentanuclear planar } \\
\text { “open”-shaped }\end{array}$ & $\mathrm{CN}^{-} / 4,4^{\prime}-$ pytz & 8-connected & $3 \mathrm{D},\left(4^{20} \cdot 6^{8}\right)$ & $7.25 \times 10^{-29}$ \\
\hline $\boldsymbol{b}$ & $\left\{\left[\mathrm{Et}_{4} \mathrm{~N}\right]_{2}\left[\mathrm{MoS}_{4} \mathrm{Cu}_{4}(\mathrm{CN})_{4}\right]\right\}_{n}$ & $\begin{array}{c}\text { pentanuclear planar } \\
\text { “open”-shaped }\end{array}$ & $\mathrm{CN}^{-}$ & 4-connected & 3D, diamondoid & $1.26 \times 10^{-29}$ \\
\hline 3 & $\left\{\left[\mathrm{WS}_{4} \mathrm{Cu}_{3}\left(4,4^{\prime}-\mathrm{pytz}\right)_{3}\right] \cdot\left[\mathrm{N}(\mathrm{CN})_{2}\right]\right\}_{n}$ & Flywheel-shaped & 4,4'-pytz & 6-connected & 3D, “ACS” & $1.44 \times 10^{-30}$ \\
\hline$c$ & $\left\{\left[\mathrm{WS}_{4} \mathrm{Cu}_{3}(\mathrm{dppm})_{3}\right] \cdot \mathrm{Br}\right\}$ & Flywheel-shaped & dppm & / & 0D, / & l \\
\hline
\end{tabular}




\title{
Tetrazine Chromophore-Based Metal-Organic Frameworks with Unusual Configurations: Synthetic, Structural, Theoretical, Fluorescent and Nonlinear Optical Studies
}

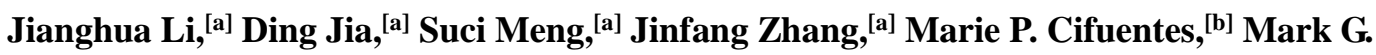 \\ Humphrey, ${ }^{[b]}$ and Chi Zhang*[a,b]

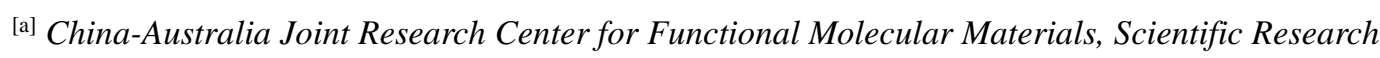 \\ Academy, Jiangsu University, Zhenjiang 212013, P. R. China

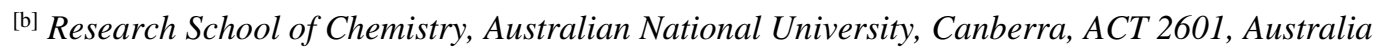

\section{TOC graphic}

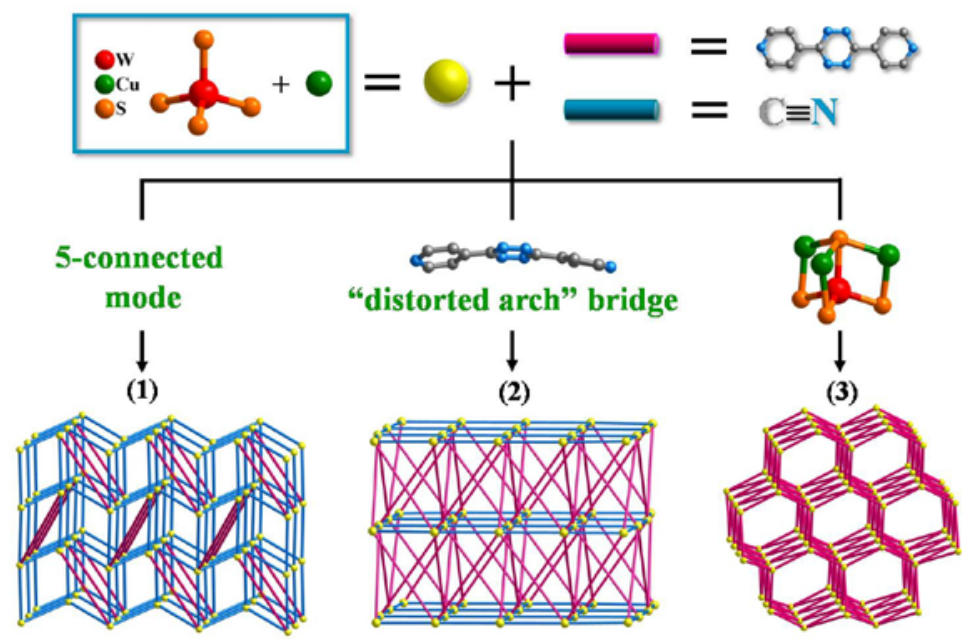

Three unusual three-dimensional (3D) tetrazine chromophore-based metal-organic frameworks 1-3 were constructed; 1 exhibits the first 5-connected $\mathrm{Mo}(\mathrm{W}) / \mathrm{S} / \mathrm{Cu}$ framework, 2 possesses a novel $\left(4^{20} \cdot 6^{8}\right)$ framework with unique “distorted arch" 4,4'-pytz bridges, and 3 is the first 3D flywheel-shaped $\mathrm{Mo}(\mathrm{W}) / \mathrm{S} / \mathrm{Cu}$ framework. The third-order nonlinear optical and steady-state fluorescence properties were assessed, and time-dependent density functional theory (TD-DFT) calculations undertaken to afford insight into the optical properties. 